\title{
Nocturnal Bees as Crop Pollinators
}

\author{
Guaraci D. Cordeiro ${ }^{1, *(1)}$, Rodolfo Liporoni ${ }^{2}{ }^{(0)}$, Carolina A. Caetano ${ }^{3}$, Cristiane Krug ${ }^{4}$, \\ Carlos A. Martínez-Martínez ${ }^{5}{ }^{1}$, Herbeson O. J. Martins ${ }^{5}$, Renan K. O. A. Cardoso ${ }^{5}$, Fernanda F. Araujo ${ }^{6}$, \\ Priscila C. S. Araújo ${ }^{7}$, Reisla Oliveira ${ }^{8}$, Clemens Schlindwein ${ }^{6}$, Eric J. Warrant ${ }^{9}{ }^{\circledR}$, Stefan Dötterl ${ }^{1}{ }^{(0)}$ \\ and Isabel Alves-dos-Santos ${ }^{10}$
}

check for

updates

Citation: Cordeiro, G.D.;

Liporoni, R.; Caetano, C.A.; Krug, C.;

Martínez-Martínez, C.A.; Martins,

H.O.J.; Cardoso, R.K.O.A.; Araujo,

F.F.; Araújo, P.C.S.; Oliveira, R.; et al.

Nocturnal Bees as Crop Pollinators.

Agronomy 2021, 11, 1014. https:/ /

doi.org/10.3390/agronomy11051014

Academic Editor: Francis Drummond

Received: 13 April 2021

Accepted: 15 May 2021

Published: 20 May 2021

Publisher's Note: MDPI stays neutral with regard to jurisdictional claims in published maps and institutional affiliations.

Copyright: (c) 2021 by the authors. Licensee MDPI, Basel, Switzerland. This article is an open access article distributed under the terms and conditions of the Creative Commons Attribution (CC BY) license (https:/ / creativecommons.org/licenses/by/ $4.0 /)$.
1 Department of Biosciences, Paris-Lodron-University of Salzburg, Hellbrunnerstr. 34, 5020 Salzburg, Austria; Stefan.Doetterl@sbg.ac.at

2 Instituto Federal de São Paulo, Campus São Miguel Paulista, São Miguel Paulista 08021-090, Brazil; rliporonid@gmail.com

3 Departamento de Ecologia e Biologia Evolutiva, Universidade Federal de São Carlos, São Carlos 13565-905, Brazil; carolinadeacaetano@gmail.com

4 Brazilian Agricultural Research Corporation (EMBRAPA), Embrapa Amazônia Ocidental, Manaus 69010-970, Brazil; cristiane.krug@embrapa.br

5 Departamento de Biologia, Faculdade de Filosofia, Ciências e Letras de Ribeirão Preto, Universidade de São Paulo, Ribeirão Preto 14040-901, Brazil; crlmartinez@usp.br (C.A.M.-M.); herbeson.martins@usp.br (H.O.J.M.); renankcardoso@gmail.com (R.K.O.A.C.)

6 Programa de Pós-Graduação em Biologia Vegetal, Departamento de Botânica, Universidade Federal de Minas Gerais, Belo Horizonte 31270-901, Brazil; figueiredofaraujo@gmail.com (F.F.A.); schlindw@gmail.com (C.S.)

7 Programa de Pós-Graduação em Zoologia, Departamento de Zoologia, Universidade Federal de Minas Gerais, Belo Horizonte 31270-901, Brazil; araujopri8@gmail.com

8 Departamento de Genética, Ecologia e Evolução, Universidade Federal de Minas Gerais, Belo Horizonte 31270-901, Brazil; reislaxoliveira@gmail.com

9 The Lund Vision Group, Department Biology, University of Lund, 22362 Lund, Sweden; eric.warrant@biol.lu.se

10 Departamento de Ecologia, Instituto de Biociências, Universidade de São Paulo, São Paulo 05508-090, Brazil; isabelha@usp.br

* Correspondence: guaradc@gmail.com

Abstract: Bees are typically diurnal but around 1\% of described species have nocturnal activity. Nocturnal bees are still poorly studied due to bias towards studying diurnal insects. However, knowledge concerning their biology and role as crop pollinators has increased. We review the literature on nocturnal bees' traits and their host plants, and assess the crop pollination effectiveness of this neglected group. Nocturnal bees have visual adaptations to cope with low light intensities, and floral scents are a key sensory cue used to find their host flowers. Nocturnal bees generally show high flower constancy, the ability to vibrate flowers, and high transfer rates of pollen grains to stigmas. The flowers visited by nocturnal bees range from small radial and zygomorphic flowers to large brush blossoms; moreover, they visit plants with different flowering strategies. Nocturnal bees are effective pollinators of regional fruit crops in Brazil, such as cambuci (Campomanesia phaea), guaraná (Paullinia cupana), cajá (Spondias mombin), and in North America of cultivated pumpkins (Cucurbita species). However, they most likely are pollinators of several other crops. Strategies to host high numbers of nocturnal bees around cropping areas should be taken, such as preserving adjacent native forests, restricting soil management, providing food resources beyond crop flowers, and avoiding light pollution.

Keywords: biodiversity; crepuscular bees; crop production; floral scent; food security; nocturnal pollination; nocturnal vision; Megalopta; Ptiloglossa

\section{Introduction}

Pollination is an essential ecosystem service and is crucial for guaranteeing global food security [1], with its economic importance estimated at USD 235-577 billion annually [2]. 
Bees are the most important crop pollinators worldwide [3], with Apis mellifera being the main managed pollinator species for crops around the world [4]. However, several crops demand specific solitary bees to guarantee efficient pollination and fruit set [5-7], and indeed, an overall high diversity of native bee pollinators enhances crop yield $[8,9]$.

Bees are typically diurnal but approximately 1\% of described species (ca. 250) have crepuscular and/or nocturnal activity. Crepuscular bees fly pre-sunrise and post-sunset, and truly nocturnal bees fly all night or for most of the night [10-14]. This behavior has arisen independently in four of the seven bee families: Andrenidae, Apidae, Colletidae, and Halictidae $[13,15]$. It is hypothesized that these bees developed nocturnal habits to escape diurnal competition for floral resources and to avoid enemies such as kleptoparasites, which are less active at night [11,15-17].

Foraging at night and during twilight is thus likely to be beneficial, as flowers are often rich in pollen and nectar early in the morning before being exploited by diurnal flower visitors [18], as well as late into the evening before nocturnal visitors arrive, providing a "competitor free space" $[12,16]$. In addition, by mainly visiting plant species with abundant floral rewards available, they would spend little time searching for host plants $[19,20]$.

Most crepuscular/nocturnal bees (hereafter referred to as nocturnal bees) occur in Neotropical regions and are widespread, mainly in South America [21]. The biology of nocturnal bees is poorly studied due to a preferential bias towards studying diurnal insects. One of the most studied and common nocturnal bee genera is Megalopta (Halictidae), which currently accounts for 32 species distributed from South Mexico to Argentina [22,23]. Megalopta bees build their nests in cavities within dead wood, and in some species more than one female per nest was recorded, suggesting a facultative social behavior [24-26]. The other abundant nocturnal bee genus, Ptiloglossa (Colletidae), has 55 described species occurring from the Southern United States to Argentina [21,27]. These bees dig tunnels in the ground to build their nests [28-30]. The genus Xylocopa has some records related to its nocturnal representatives, as X. tranquebarica from Asia [31]. Besides these, there are other genera of nocturnal bees, such as Megommation, Zikanapis, and Xenoglossa [15,32] (Figure 1). There are species with facultative nocturnal behavior that forage during the day but occasionally have also been reported at night, among them Apis dorsata, A. mellifera adansonii, and other Xylocopa species [12,33].
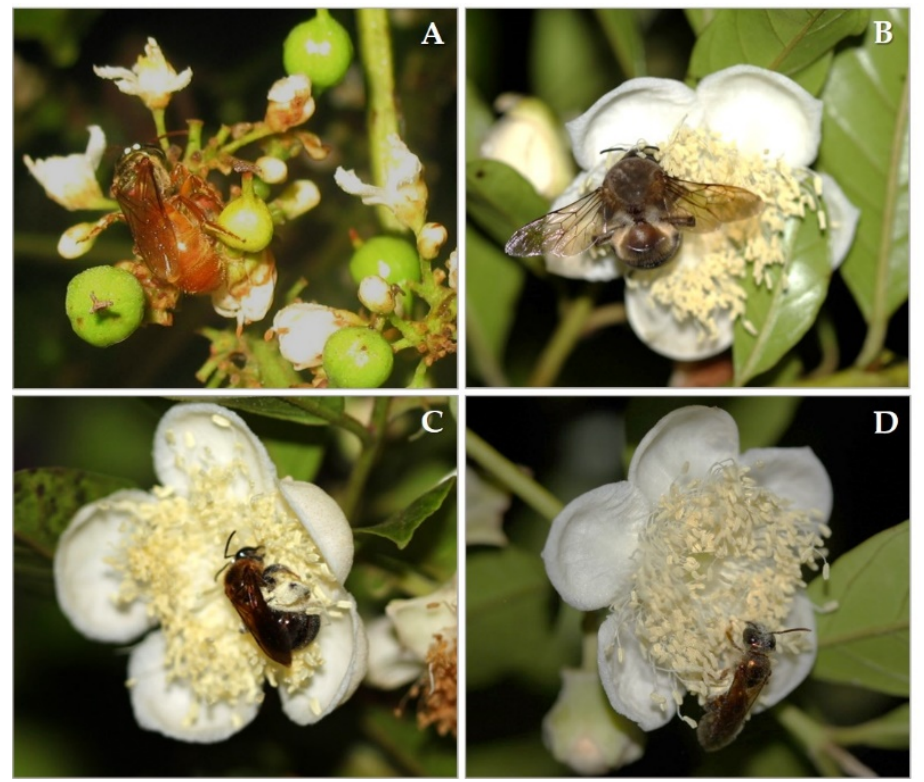

Figure 1. Nocturnal bees: (A) Megalopta aeneicollis, (B) Ptiloglossa latecalcarata, (C) Megommation insigne, (D) Megalopta sodalis. 
These bees visit a high number of plant species, among them crops [34]. The pollination efficiency of nocturnal bees was recently shown for Brazilian crops of different families, such as Anacardiaceae (Spondias mombin), Myrtaceae (Campomanesia phaea), and Sapindaceae (Paullinia cupana) [18,35-37], but they are potential pollinators of other crops as well $[38,39]$. Here, we review the literature on nocturnal bees: how they find flowers, their pollinator traits and host plants, and assess the crop pollination effectiveness of this neglected group. We then address perspectives on how to provide appropriate habitats to improve the presence of nocturnal bees around cropping areas to facilitate pollination.

\section{How Do Nocturnal Bees Find Flowers in the Darkness?}

Bees use visual (shape, brightness, and color) as well as chemical (scent) floral cues to find flowers and to obtain food resources such as nectar and pollen [40-42]. As nocturnal bees have a very restricted period of activity to collect their food resources (ca. 1-2 h), one might expect that these bees need to be very efficient at finding flowers. Compared to diurnal bees, nocturnal bees have several visual adaptations to cope with low light intensities. They typically have larger apposition compound eyes and ocelli [10,43-45], optical mechanisms for increasing light capture in dim light $[10,13,44,46-49]$, and specialized neural mechanisms that enhance visual performance by boosting retinal signal reliability [50] and by summing photons in space and time $[13,47,51,52]$. Light intensity thresholds determine flower search behavior more than other abiotic environmental factors [11,53]. Moreover, nocturnal bees tend to visit flowers with a broad reflection spectrum that likely creates a high contrast white target against the dark backgrounds of the sky and vegetation [53-56].

In addition to visual adaptations for dim light, nocturnal pollinators often heavily depend on floral odors to find their host flowers [55]. Indeed, nocturnal bees tend to visit and are attracted by flowers releasing a strong perfume at night $[20,39,56]$, with volatiles from various biosynthetic routes. For example, nocturnal bees are attracted to the strong scent of Campomanesia phaea (Myrtaceae) flowers, which is mainly composed of aromatic (2phenylethanol and benzyl alcohol) and aliphatic (1-octanol and 1-hexanol) compounds [18]. The floral scents emitted by Paullinia cupana (Sapindaceae) and attractive as a mixture to nocturnal bee pollinators are, among others, the terpenoids linalool and $(E)$ - $\beta$-ocimene, and the nitrogen-bearing compound phenylacetonitrile [36]. These available data demonstrate that strong floral scents composed of compounds widespread among flower scents [57] are a key sensory cue used by nocturnal bees to find their host flowers.

\section{Traits of Nocturnal Bees and Their Host Plants}

As diurnal bees, nocturnal bees depend on floral resources to survive and feed their offspring, and actively seek flowers from which to take up nectar and collect pollen. Some of the pollen grains thereby adhere to the pilosity of their body surface. These grains can subsequently be passively deposited on the stigma of conspecific flowers, completing the pollination process [58]. Nocturnal bees generally show high flower constancy since individual bees preferentially visit flowers of the conspecific species during a foraging flight, as observed in Myrtaceae [18,38,39,59] and Caryocaraceae [20]. Furthermore, nocturnal bees are able to vibrate flowers (Supplementary Material), which is a quite efficient mechanism for collecting pollen $[33,60,61]$. This behavior was even observed in plant species with non-poricidal anthers $[18,39,59]$. In one case, nocturnal bees have been shown to transfer higher quantities of pollen grains to the stigma of flowers than diurnal bees [18], and are sometimes more abundant floral visitors than diurnal bees [18,62].

Nocturnal bees explore different types of flowers. Some floral features certainly favor pollination or visitation by nocturnal bees, such as nocturnal anthesis, high light reflectance, and a strong perfume. However, the forms and sizes of flowers visited by nocturnal bees are quite variable. Among such flowers are large brush blossoms (e.g., Caryocar brasiliense) [20], small zygomorphic flowers (e.g., Paullinia cupana) [36,37], keel flowers (e.g., Machaerium opacum) [56], and disk flowers (e.g., Myrtaceae species) [18,39]. Nocturnal bees also visit plants with different flowering strategies, like those with mass 
(e.g., Plinia cauliflora, Machaerium opacum) or steady-state flowering (e.g., Campomanesia phaea, Eugenia pyriformis) $[18,39,56,63]$.

\section{Host Plants of Nocturnal Bees}

Nocturnal bees visit a wide spectrum of wild and crop plants and they can efficiently pollinate some of them, such as Cambessedesia wurdackii (Melastomataceae) [62], Campomanesia phaea (Myrtaceae) [18], Paullinia cupana (Sapindaceae) [36,37], Machaerium opacum (Fabaceae) [56], Passiflora pohlii (Passifloraceae) [64], Trembleya laniflora (Melastomataceae) [33], and Cucurbita species (Cucurbitaceae) [65,66]. Several other species are visited by nocturnal bees, but there is still little information about their pollination efficiency. Among such species are Calathea insignis (Marantaceae) [67], Gustavia augusta (Lecythidaceae) [68], Parkia velutina (Fabaceae) [69], Ipomea species (Convolvulaceae) [70,71], Solanum species (Solanaceae) [30,67,72,73], and Eugenia, Syzygium, and Plinia species (Myrtaceae) [39].

Pollen analysis from brood cells of nocturnal bees, or from pollen attached to their bodies, has shown that these bees also visit several chiropterophilous (bat-pollinated) and sphingophilous (moth-pollinated) species [16,19,34,74]. However, in only a few cases has the role of nocturnal bees as pollinators of these plants been studied. In the batpollinated Cayaponia cabocla (Cucurbitaceae), they are potential pollinators [75], but in the bat-pollinated tree Caryocar brasiliense, they efficiently remove floral resources without contributing to fruit set [20]. In chiropterophilous and sphingophilous flowers that provide easily accessible flowers with abundant pollen and nectar, nocturnal bees seem to generally be poor pollinators due to their morphological mismatch [20].

Moreover, nocturnal bees are generalists with regard to their food resources, and highly opportunistic. For instance, Megalopta bees captured on field bioassays in guaraná crops carried only pollen grains of this crop on their body, but other individuals of the same species also carried pollen of other species, mainly Arecaceae and Euphorbiaceae species [36]. Analysis of brood cell provisions of two Megalopta species has revealed pollen of 64 plant species from 19 families [34]. Bees of Ptiloglossa also visit different nightflowering plants, but in one single brood cell a monofloral pollen load was found [20]. The Paleotropical bee species X. tranquebarica, which visits flowers throughout the night, seems to be a generalist, as it was found to feed on diurnal leftovers from 71 plant species [76].

\section{Nocturnal Bees as Crop Pollinators}

Our knowledge concerning crop pollination by nocturnal bees has increased recently (Table 1). Nocturnal bees have been recorded to be effective pollinators of regional crops in Brazil, such as cambuci (Campomanesia phaea-Myrtaceae), which are native to the Atlantic Forest, and guaraná (Paullinia cupana-Sapindaceae), native to the Amazon region. Both species are cultivated in their original habitat and both have regional economic importance $[18,36,37,77]$. Nocturnal bees most likely are pollinators of other Myrtaceae crops in the neotropics, for example of species in the genera Eugenia, Campomanesia, Myrcia, and Pisidium, which produce fleshy fruits. Flower opening before sunrise and an intense floral scent is common to all these species $[18,38,39,59]$.

Nocturnal bees also pollinate flowers of cajá (yellow mombin, Spondias mombinAnacardiaceae [35], which is an economically important and common fruit crop native to and cultivated in Northeast and Northern Brazil, and Central America. The genus Spondias includes other frequently used fruit crop species (e.g., S. purpurea, S. tuberosa) with similar blossoms, nocturnal anthesis periods, and floral resources [78,79], that also might be pollinated by nocturnal bees.

In North America, squash bees of the genera Peponapis and Xenoglossa display crepuscular flight activity that begins before sunrise. Xenoglossa is only active during twilight, whereas Peponapis also forages throughout the day $[65,66,80,81]$. Both species are oligolectic on species of Cucurbita (Cucurbitaceae) and effective pollinators of cultivated pumpkins (Cucurbita foetidissima, C. maxima, C. pepo). 
Nocturnal bees visit flowers of a broad spectrum of families (at least 40 families) [82], such as Fabaceae, an important group of cultivated plants, where they show the ability to open the keel, typical for flowers of this family [56]. Their capacity to vibrate flowers to collect pollen makes nocturnal bees potential pollinators of a range of cultivated plants with poricidal anthers, such as Solanum species (eggplant, peppers, tomato) $[30,56,72,73]$.

Table 1. List of crop plant families and species known to be pollinated ( $\mathrm{E}=$ effective, $\mathrm{P}=$ potential pollination) by nocturnal bees; nocturnal bee genera that visit them; geographical occurrence; references (Ref.).

\begin{tabular}{|c|c|c|c|c|c|}
\hline Plant Family & $\begin{array}{l}\text { Plant Species } \\
\text { (Popular Name) }\end{array}$ & $\begin{array}{l}\text { Nocturnal Bee } \\
\text { Genera }\end{array}$ & Role as Pollinators & Occurrence & Ref. \\
\hline \multirow[t]{2}{*}{ Anacardiaceae } & $\begin{array}{c}\text { Spondias mombin } \\
\text { (cajá, yellow mombin) }\end{array}$ & Megalopta, Ptiloglossa & $\mathrm{E}$ & $\begin{array}{l}\text { Caatinga- } \\
\text { Brazil }\end{array}$ & {$[35]$} \\
\hline & Spondias pinnata (wild mango) & Xylocopa & $\mathrm{P}$ & $\begin{array}{l}\text { Tropical } \\
\text { Forest-Southeast Asia }\end{array}$ & {$[83]$} \\
\hline \multirow[t]{3}{*}{ Cucurbitaceae } & $\begin{array}{l}\text { Cucurbita foetidissima } \\
\text { (pumpkin) }\end{array}$ & $\begin{array}{l}\text { Peponapis, } \\
\text { Xenoglossa }\end{array}$ & $\mathrm{E}$ & $\begin{array}{l}\text { Dry environments- } \\
\text { Mexico/USA }\end{array}$ & {$[81]$} \\
\hline & $\begin{array}{c}\text { Cucurbita maxima } \\
\text { (pumpkin) }\end{array}$ & $\begin{array}{l}\text { Peponapis, } \\
\text { Xenoglossa }\end{array}$ & $\mathrm{E}$ & $\begin{array}{l}\text { Dry environments- } \\
\text { Mexico/USA }\end{array}$ & {$[80]$} \\
\hline & Cucurbita pepo (pumpkin) & $\begin{array}{l}\text { Peponapis, } \\
\text { Xenoglossa }\end{array}$ & $\mathrm{E}$ & $\begin{array}{l}\text { Dry environments- } \\
\text { Mexico/USA }\end{array}$ & {$[65,66,80]$} \\
\hline \multirow[t]{17}{*}{ Myrtaceae } & Campomanesia phaea (cambuci) & $\begin{array}{c}\text { Megalopta, Ptiloglossa, } \\
\text { Megommation, } \\
\text { Zikanapis }\end{array}$ & $\mathrm{E}$ & $\begin{array}{l}\text { Atlantic Forest- } \\
\text { Brazil }\end{array}$ & {$[18]$} \\
\hline & $\begin{array}{c}\text { Campomanesia pubescens } \\
\text { (gabiroba) }\end{array}$ & $\begin{array}{l}\text { Megalopta, } \\
\text { Ptiloglossa }\end{array}$ & $\mathrm{E}$ & $\begin{array}{l}\text { Atlantic Forest, } \\
\text { Cerrado-Brazil }\end{array}$ & {$[84]$} \\
\hline & $\begin{array}{c}\text { Eugenia brasiliensis } \\
\text { (grumixama) }\end{array}$ & Megommation & $\mathrm{P}$ & $\begin{array}{l}\text { Atlantic Forest- } \\
\text { Brazil }\end{array}$ & {$[39]$} \\
\hline & $\begin{array}{c}\text { Eugenia dysenterica } \\
\text { (cagaita) }\end{array}$ & Ptiloglossa & $\mathrm{P}$ & Cerrado-Brazil & {$[39]$} \\
\hline & $\begin{array}{l}\text { Eugenia florida } \\
\text { (guamirim) }\end{array}$ & Megalopta & $\mathrm{E}$ & $\begin{array}{l}\text { Amazon, Atlantic } \\
\text { Forest, Caatinga, } \\
\text { Cerrado-Brazil }\end{array}$ & {$[59]$} \\
\hline & $\begin{array}{c}\text { Eugenia involucrata } \\
\text { (cereja-do-Rio-Grande) }\end{array}$ & $\begin{array}{c}\text { Megalopta, } \\
\text { Megommation }\end{array}$ & $\mathrm{P}$ & $\begin{array}{l}\text { Atlantic Forest- } \\
\text { Brazil }\end{array}$ & {$[39]$} \\
\hline & $\begin{array}{l}\text { Eugenia neonitida } \\
\text { (pitangatuba) }\end{array}$ & Ptiloglossa & $\mathrm{P}$ & $\begin{array}{c}\text { Atlantic Forest- } \\
\text { Brazil }\end{array}$ & {$[38]$} \\
\hline & $\begin{array}{l}\text { Eugenia punicifolia } \\
\text { (cereja-do-cerrado) }\end{array}$ & Ptiloglossa & $\mathrm{P}$ & $\begin{array}{l}\text { Amazon, Atlantic } \\
\text { Forest, Caatinga, } \\
\text { Cerrado-Brazil }\end{array}$ & {$[38]$} \\
\hline & $\begin{array}{c}\text { Eugenia pyriformis } \\
\text { (uvaia) }\end{array}$ & Ptiloglossa & $\mathrm{P}$ & $\begin{array}{c}\text { Atlantic Forest- } \\
\text { Brazil }\end{array}$ & {$[39]$} \\
\hline & $\begin{array}{l}\text { Eugenia rotundifolia } \\
\text { (abajurú) }\end{array}$ & Ptiloglossa & $\mathrm{P}$ & $\begin{array}{l}\text { Atlantic Forest- } \\
\text { Brazil }\end{array}$ & {$[38]$} \\
\hline & $\begin{array}{c}\text { Eugenia stipitata } \\
\text { (araçá-boi) }\end{array}$ & $\begin{array}{c}\text { Megalopta, } \\
\text { Megommation }\end{array}$ & $\mathrm{P}$ & $\begin{array}{l}\text { Amazon, Atlantic } \\
\text { Forest-Brazil }\end{array}$ & {$[39,85]$} \\
\hline & $\begin{array}{l}\text { Eugenia uniflora } \\
\text { (pitanga) }\end{array}$ & Ptiloglossa & $\mathrm{P}$ & $\begin{array}{c}\text { Atlantic Forest- } \\
\text { Brazil }\end{array}$ & {$[38,39]$} \\
\hline & Myrciaria floribunda (cambuí) & Megalopta & $\mathrm{E}$ & $\begin{array}{l}\text { Amazon, Atlantic } \\
\text { Forest, Caatinga, } \\
\text { Cerrado-Brazil }\end{array}$ & {$[59]$} \\
\hline & $\begin{array}{l}\text { Myrciaria dubia } \\
\text { (camu-camu) }\end{array}$ & Megalopta & $\mathrm{P}$ & Amazon-Brazil & {$[86]$} \\
\hline & $\begin{array}{c}\text { Plinia cauliflora } \\
\text { (jabuticaba) }\end{array}$ & Ptiloglossa & $\mathrm{P}$ & $\begin{array}{l}\text { Atlantic Forest, } \\
\text { Cerrado-Brazil }\end{array}$ & {$[39]$} \\
\hline & $\begin{array}{l}\text { Psidium acutangulum } \\
\text { (araçá-pera) }\end{array}$ & Megalopta & $\mathrm{P}$ & Amazon-Brazil & [87] \\
\hline & $\begin{array}{l}\text { Syzygium malaccense } \\
\text { (jambo-rosa) }\end{array}$ & Ptiloglossa & $\mathrm{P}$ & $\begin{array}{c}\text { Atlantic Forest- } \\
\text { Brazil }\end{array}$ & {$[39]$} \\
\hline Sapindaceae & $\begin{array}{l}\text { Paullinia cupana } \\
\text { (guaraná) }\end{array}$ & Megalopta, Ptiloglossa & $\mathrm{E}$ & Amazon-Brazil & {$[36,37]$} \\
\hline
\end{tabular}

This demonstrates not only the great potential of nocturnal bees as pollinators but also the necessity of extending observations in crops with nocturnal anthesis to analyze their contribution to pollination and food production in species of economic interest. 


\section{Requirements on Crop Areas to Host High Numbers of Nocturnal Bees}

The biology of nocturnal bees is still poorly understood, and there is no possibility of acquiring nests commercially, as is possible for diurnal bees (e.g., Osmia, Megachile, bumblebees, stingless bees or honeybees), but some strategies to provide appropriate habitats to improve their presence around cropping areas will now be suggested (Box 1, Figure 2).

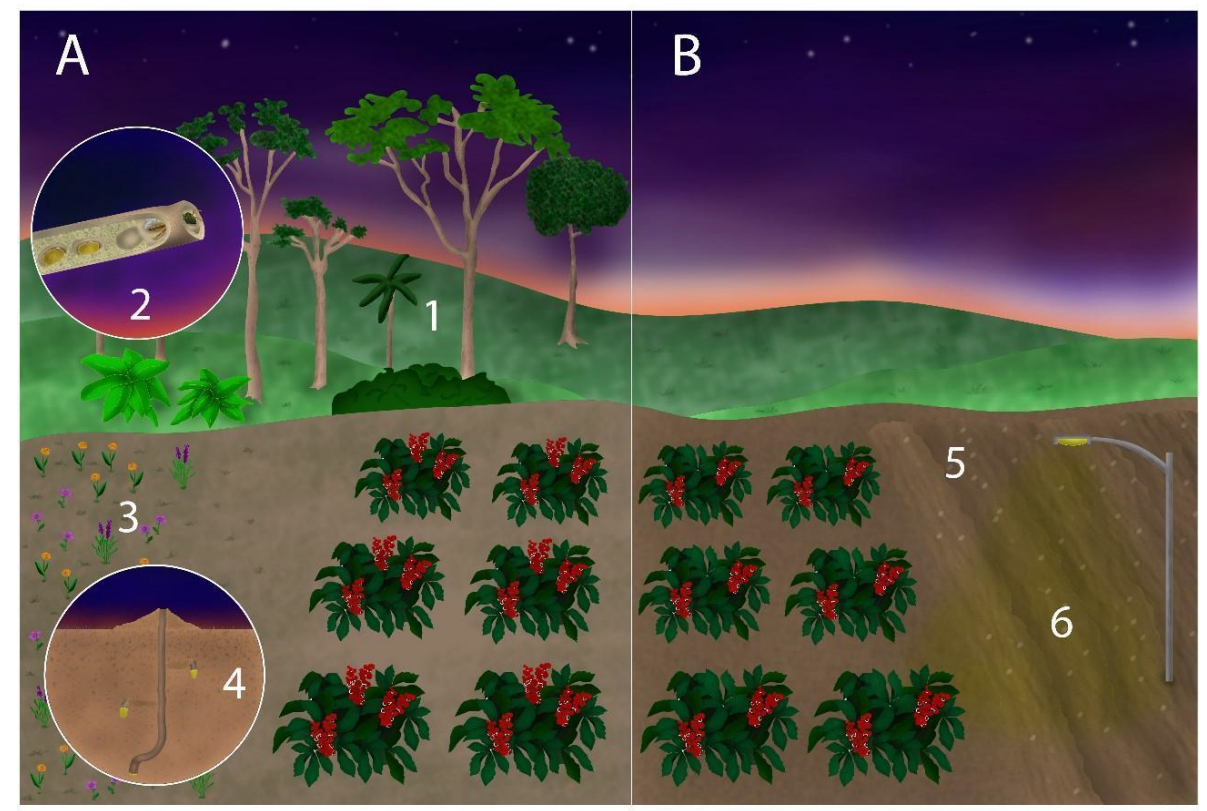

Figure 2. Comparing a more (A) and a less (B) sustainable crop area for hosting high numbers of nocturnal bee pollinators. Adjacent natural areas to provide food (1) and nest (2) resources; a range of cultivated, native flowering species offer food beyond the crop flowering season (3); potential nesting sites of ground-nesting species (e.g., Ptiloglossa) should be identified and protected (4); soil disturbance, such as that caused by deep tillage, fire, and superficial movements in the area by agricultural machines should be minimized, at least during the flowering season (5); artificial light pollution at night (ALAN) near crop areas should be avoided (6).

Box 1. Summary of nocturnal bee traits and needs in crop areas.

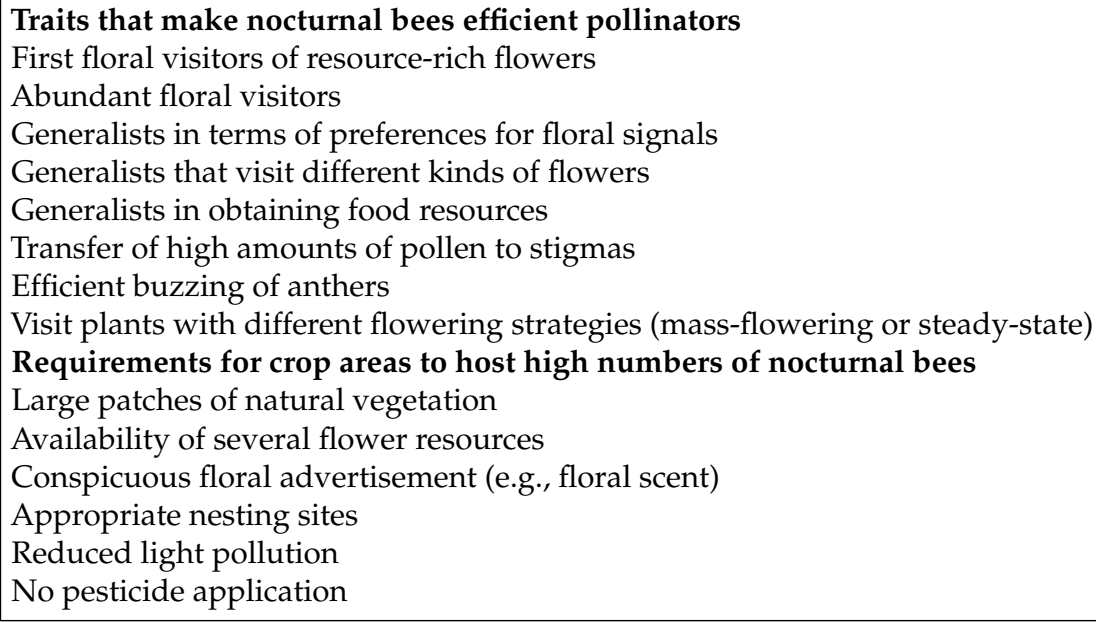

Nocturnal bees typically nest around or within forest patches in the ground (e.g., Ptiloglossa, Zikanapis, Megommation) or in tree wood (Megalopta). Most crops known to be pollinated by nocturnal bees are surrounded by patches of native forest $[18,36,37,59]$. This indicates nocturnal bees' affinity to diverse native habitats with available flowers 
and nesting sites nearby. In the context of fluctuating, or even disappearing resource environments, any sustainable practices that ensure a local diversity of flowers and nesting sites are essential, such as agroforestry management strategies. Moreover, if a crop can only offer pollen as a resource (e.g., Myrtaceae species) to nocturnal bees, it would be beneficial to provide other plants that also provide nectar, and vice versa. Furthermore, if the crop has a short blooming period, such as cambuci and guaraná, it is necessary to preserve further food sources beyond the crop flowering seasons [88]. Thus, future studies are needed to determine which wild plants are also able support nocturnal bees.

Based on these characteristics, crop producers should preserve native forest reserves adjacent to the cropping area as much as possible and restrict management of the soil, especially during the flowering season. For instance, nest aggregations of Peponapis and Xenoglossa are found near or even at the edge of pumpkin patches, and tilled soil disturbs their population and renders them less frequent in Cucurbita flowers [66,89]. Therefore, it is crucial to identify potential nests of nocturnal bees that build aggregations and to isolate the nesting site, to avoid movements by agricultural machines that could damage the nests. Moreover, the practice of applying pesticides should be avoided if the crop can potentially be pollinated with nocturnal bees.

Another factor to consider is light pollution. Nocturnal bees are traditionally captured by a range of different light-based traps, indicating that they are easily attracted by artificial white light and dark (UV) light [90]. Moreover, light is the most important factor controlling the activity of nocturnal bees at nests and flowers [53,54]. Thus, changes in natural light intensities, as might be caused by local light pollution, could affect their flight and pollination services. This so-called artificial light pollution at night (ALAN) is estimated to interfere with the nocturnal visits of pollinators to their host plants, reducing nocturnal visitation by up to $62 \%$ [91]. Moreover, light pollution can affect pollinator behavior, as seen in moths spending more time at artificial light sources than at flowers [92]. However, LED lamps have fewer negative effects, and tree cover can mitigate the effect of ALAN on nocturnal moth pollinators [93]. Therefore, even though more studies are necessary that investigate the effect of light pollution on nocturnal bee pollination, it is advised that local farmers should maintain artificial light sources as far as possible from orchards and crop areas, and keep their intensity at low levels, especially during twilight, since outdoor lighting can certainly disturb bees and deviate them from flowers.

\section{Conclusions}

As pollination is an essential service for world food security, we must understand and protect its agents, and this includes pollinators that have, to date, been relatively neglected, such as nocturnal bees. The role of nocturnal bees was, until recently, largely overlooked, since these bees were rarely seen or collected. However, as soon as nocturnal bees were studied in more detail, their importance as pollinators was determined to be much greater than previously reported. Long before the visits of diurnal bees, nocturnal bees are already in the flowers and have already contributed to plant reproduction. Thus, night-blooming crop species need to be reevaluated to determine whether nocturnal bees visit their flowers and if so, which species are visiting, and during which months and at which times during the night visits occur. It will also be necessary to investigate how these bees participate in the pollination of their hosts. Most plants mentioned visited by nocturnal bees also have diurnal anthesis and are also visited by diurnal bee species. Therefore, it is important to determine whether the pollination roles for nocturnal and diurnal species are complementary.

In this review, nocturnal bees were identified as effective pollinators of some crop species and potential pollinators of others. When attempting to take advantage of nocturnal bees as pollinators of crops, some precautions should be taken by farmers, such as soil management, provision of other food resources to local bees, and control of light pollution. In a world facing the challenges of climate change, habitat destruction, and biodiversity 
loss, there is an urgent need to rescue as many crop pollinators as possible around the globe, including nocturnal bees.

\section{Outstanding Questions for Future Studies}

Are there other crops, apart from those we currently know, that are pollinated by nocturnal bees?

During which months (or seasons) of the year are nocturnal bees active in crop pollination?

What is the contribution of nocturnal bees, both biologically and economically, to the pollination of crop plants?

Are the crop pollination roles of nocturnal and diurnal bees complementary?

How do scent, brightness, and color of flowers interact to attract nocturnal bees?

How does light pollution affect nocturnal bee pollination in crop areas?

Is there any level of artificial light that can actually increase/decrease flower visitation by nocturnal bees and perhaps influence yields?

How does the wavelength composition of artificial light (i.e., different colors) affect the foraging activity of nocturnal bees?

Apart from crops, which wild plants support nocturnal bees?

Supplementary Materials: The following are available online at https://www.mdpi.com/article/ 10.3390/agronomy11051014/s1, Video S1: Ptiloglossa latecalcarata (Colletidae) vibrating flowers of Campomanesia phaea (Myrtaceae) before sunrise.

Author Contributions: Conceptualization, G.D.C. and I.A.-d.-S.; writing-original draft preparation, G.D.C., R.L. and I.A.-d.-S.; writing-review and editing, G.D.C., R.L., C.A.C., C.K., C.A.M.-M., H.O.J.M., R.K.O.A.C., F.F.A., P.C.S.A., R.O., C.S., E.J.W., S.D., I.A.-d.-S.; supervision, S.D., I.A.-d.-S.; project administration, S.D., I.A.-d.-S.; funding acquisition, S.D., E.J.W. and I.A.-d.-S. All authors have read and agreed to the published version of the manuscript.

Funding: This research was funded by CNPq (Grant No. PVE 401466/2014-0) to I.A.-d.-S., C.S., S.D. and CNPq (PQ 311935/2018-4), Universal (436095/2018-1), Fundação de Amparo à Pesquisa do Estado de Minas Gerais (FAPEMIG Universal, APQ-00713-17) to C.S.

Acknowledgments: We are grateful to Claudia Inês da Silva and Sidnei Mateus for helping in all our collecting field data. We are also grateful to farmers allowing us to perform the studies on their proprieties.

Conflicts of Interest: The authors declare no conflict of interest.

\section{References}

1. United Nations. Open Working Group Proposal for Sustainable Development Goals; Full Report A/68/970; Open Working Group of the General Assembly on Sustainable Development Goals, United Nations: Geneva, Switzerland, 2014.

2. Potts, S.G.; Imperatriz-Fonseca, V.L.; Ngo, H.T.; Aizen, M.A.; Biesmeijer, J.C.; Breeze, T.D.; Dicks, L.V.; Garibaldi, L.A.; Hill, R.; Settele, J.; et al. Safeguarding pollinators and their values to human well-being. Nature 2016, 540, 220-229. [CrossRef]

3. Klein, A.; Vaissiere, B.E.; Cane, J.H.; Steffan-Dewenter, I.; Cunningham, S.A.; Kremen, C.; Tscharntke, T. Importance of pollinators in changing landscapes for world crops. Proc. R. Soc. Lond. 2007, 274, 303-313. [CrossRef]

4. Aizen, M.A.; Harder, L.D. The global stock of domesticated honeybees is growing slower than agricultural demand for pollination. Curr. Biol. 2009, 19, 915-918. [CrossRef] [PubMed]

5. Freitas, B.; Paxton, R.A. Comparison of two pollinators: The introduced honey bee Apis mellifera and an indigenous bee Centris tarsata on Cashew Anacardium occidentale in its native range of NE Brazil. J. Appl. Ecol. 1998, 35, 109-121. [CrossRef]

6. Oliveira, R.; Schlindwein, C. Searching for a manageable pollinator for acerola orchards: The solitary oil-collecting bee Centris analis (Hymenoptera: Apidae: Centridini). J. Econ. Entomol. 2009, 102, 265-273. [CrossRef] [PubMed]

7. Giannini, T.C.; Alves, D.A.; Alves, R.; Cordeiro, G.D.; Campbell, A.J.; Awade, M.; Bento, J.M.S.; Saraiva, A.M.; Imperatriz-Fonseca, V.L. Unveiling the contribution of bee pollinators to Brazilian crops with implications for bee management. Apidologie 2020, 51, 406-421. [CrossRef]

8. Garibaldi, L.A.; Steffan-Dewenter, I.; Winfree, R.; Aizen, M.A.; Bommarco, R.; Cunningham, S.A.; Kremen, C.; Carvalheiro, L.G.; Harder, L.D.; Afik, O.; et al. Wild pollinators enhance fruit set of crops regardless of honeybee abundance. Science 2013, 339, 1608-1611. [CrossRef] 
9. Woodcock, B.A.; Garratt, M.P.D.; Powney, G.D.; Shaw, R.F.; Osborne, J.L.; Soroka, J.; Lindström, S.A.M.; Stanley, D.; Ouvrard, P.; Edwards, M.E.; et al. Meta-analysis reveals that pollinator functional diversity and abundance enhance crop pollination and yield. Nat. Commun. 2019, 10, 1481. [CrossRef] [PubMed]

10. Warrant, E.J.; Kelber, A.; Gislén, A.; Greiner, B.; Ribi, W.; Wcislo, W.T. Nocturnal vision and landmark orientation in a tropical halictid bee. Curr. Biol. 2004, 14, 1309-1318. [CrossRef]

11. Kelber, A.; Warrant, E.J.; Pfaff, M.; Wallén, R.; Theobald, J.C.; Wcislo, W.T.; Raguso, R.A. Light intensity limits foraging activity in nocturnal and crepuscular bees. Behav. Ecol. 2006, 17, 63-72. [CrossRef]

12. Warrant, E.J. Nocturnal bees. Curr. Biol. 2007, 17, 991-992. [CrossRef]

13. Warrant, E.J. Seeing in the dark: Vision and visual behaviour in nocturnal bees and wasps. J. Exp. Biol. 2008, 211, 1737-1746. [CrossRef] [PubMed]

14. Somanathan, H.; Borges, R.M.; Warrant, E.J.; Kelber, A. Visual ecology of Indian carpenter bees I: Light intensities and flight activity. J. Comp. Physiol. A 2008, 194, 97-107. [CrossRef] [PubMed]

15. Wcislo, W.T.; Tierney, S.M. Behavioural environments and niche construction: The evolution of dim-light foraging in bees. Biol. Rev. 2009, 84, 19-37. [CrossRef] [PubMed]

16. Wcislo, W.T.; Arneson, L.; Roesch, K.; Gonzalez, V.; Smith, A.; Fernandez, H. The evolution of nocturnal behavior in sweat bees, Megalopta genalis and M. ecuadoria (Hymenoptera: Halictidae): An escape from competitors and enemies? Biol. J. Linn. Soc. 2004, 83, 377-387. [CrossRef]

17. Smith, A.R.; Kitchen, S.M.; Toney, R.M.; Ziegler, C. Is nocturnal foraging in a tropical bee an escape from interference competition? J. Insect Sci. 2017, 17, 62. [CrossRef] [PubMed]

18. Cordeiro, G.D.; Pinheiro, M.; Dötterl, S.; Alves-dos-Santos, I. Pollination of Campomanesia phaea (Myrtaceae) by night-active bees: A new nocturnal pollination system mediated by floral scent. Plant Biol. 2017, 19, 132-139. [CrossRef]

19. Roulston, T.H. Hourly capture rates of two species of Megalopta (Hymenoptera: Apoidea; Halictidae) at black lights in Panama with notes on nocturnal foraging by bees. J. Kans. Entomol. Soc. 1997, 70, 189-196.

20. Araujo, F.F.; Araújo, P.C.S.; Siqueira, E.; Alves-dos-Santos, I.; Oliveira, R.; Dötterl, S.; Schlindwein, C. Nocturnal bees exploit but do not pollinate flowers of a common bat-pollinated tree. Arthropod Plant Interact. 2020, 14, 785-797. [CrossRef]

21. Ascher, J.S.; Pickering, J. Discover Life Bee Species Guide and World Checklist (Hymenoptera: Apoidea: Anthophila). Available online: http: / / www.discoverlife:mp/20q?guide=Apoidea_species (accessed on 31 March 2021).

22. Moure, J.S. Augochlorini Beebe. In Catalogue of Bees (Hymenoptera, Apoidea) in the Neotropical Region Online Version; Moure, J.S., Urban, D., Melo, G.A.R., Eds.; Sociedade Brasileira de Entomologia: Curitiba, Brazil, 2007.

23. Santos, L.M.; Melo, G.A.R. Updating the taxonomy of the bee genus Megalopta (Hymenoptera: Apidae, Augochlorini) including revision of the Brazilian species. J. Nat. Hist. 2015, 49, 575-674. [CrossRef]

24. Wcislo, W.T.; Gonzalez, V.H. Social and ecological contexts of trophallaxis in facultatively social sweat bees, Megalopta genalis and M. ecuadoria (Hymenoptera, Halictidae). Insectes Soc. 2006, 53, 220-225. [CrossRef]

25. Tierney, S.M.; Gonzales-Ojeda, T.; Wcislo, W.T. Biology of a nocturnal bee, Megalopta atra (Hymenoptera: Halictidae; Augochlorini), from the Panamanian highlands. J. Nat. Hist. 2008, 42, 1841-1847. [CrossRef]

26. Santos, L.M.; Tierney, S.M.; Wcislo, W.T. Nest descriptions of Megalopta aegis (Vachal) and M. guimaraesi Santos \& Silveira (Hymenoptera, Halictidae) from the Brazilian Cerrado. Rev. Bras. Entomol. 2010, 54, 332-334. [CrossRef]

27. Urban, D.; Moure, J.S.; Melo, G.A.R. Diphaglossini Vachal. In Catalogue of Bees (Hymenoptera, Apoidea) in the Neotropical Region Online Version; Moure, J.S., Urban, D., Melo, G.A.R., Eds.; Sociedade Brasileira de Entomologia: Curitiba, Brazil, 2007.

28. Roberts, R.B. Biology of the crepuscular bee Ptiloglossa guinnae n. sp. with notes on associated bees, mites and yeasts. J. Kans. Entomol. Soc. 1971, 44, 283-294.

29. Rozen, J.G. Nesting biology of Diphaglossine bees (Hymenoptera, Colletidae). Am. Mus. Novit. 1984, $2786,1-33$.

30. Sarzetti, L.C.; Genise, F.F.; Sánchez, V.M.; Farina, J.L.; Molina, A.M. Nesting behavior and ecological preferences of five Diphaglossinae species (Hymenoptera, Apoidea, Colletidae) from Argentina and Chile. J. Hymenop. Res. 2013, $33,63-82$. [CrossRef]

31. Keasar, T. Large carpenter bees as agricultural pollinators. Psyche 2010, 927463, 1-7. [CrossRef]

32. Michener, C.D. The Bees of the World, 2nd ed.; Johns Hopkins University Press: Baltimore, MD, USA, 2007 ; p. 953.

33. Soares, N.C.; Morellato, L.P.C. Crepuscular pollination and reproductive ecology of Trembleya laniflora (Melastomataceae), an endemic species in mountain rupestrian grasslands. Flora 2018, 238, 138-147. [CrossRef]

34. Smith, A.R.; López-Quintero, I.J.; Moreno-Patiño, J.E.; Roubik, D.W.; Wcislo, W.T. Pollen use by Megalopta sweat bees in relation to resource availability in a tropical forest. Ecol. Entomol. 2012, 37, 309-317. [CrossRef]

35. Carneiro, L.; Martins, C.F. Africanized honeybees pollinate and preempt the pollen of Spondias mombin (Anacardiaceae) flowers. Apidologie 2012, 43, 474-486. [CrossRef]

36. Krug, C.; Cordeiro, G.D.; Schäffler, I.; Silva, C.I.; Oliveira, R.; Schlindwein, C.; Dötterl, S.; Alves-dos-Santos, I. Nocturnal bee pollinators are attracted to Guarana flowers by their scents. Front. Plant Sci. 2018, 9, 1072. [CrossRef] [PubMed]

37. Krug, C.; Garcia, M.V.B.; Gomes, F.B. A scientific note on new insights in the pollination of guarana (Paullinia cupana var. sorbilis). Apidologie 2015, 46, 164-166. [CrossRef]

38. Silva, A.L.G.; Pinheiro, M.C.B. Biologia floral e da polinização de quatro espécies de Eugenia L. (Myrtaceae). Acta Bot. Bras. 2007, 21, 235-247. [CrossRef] 
39. Cordeiro, G.D.; Santos, I.G.F.; Silva, C.I.; Schlindwein, C.; Alves-dos-Santos, I.; Dötterl, S. Nocturnal floral scent profiles of Myrtaceae fruit crops. Phytochemistry 2019, 162, 193-198. [CrossRef]

40. Dötterl, S.; Vereecken, N. The chemical ecology and evolution of bee-flower interactions: A review and perspectives. Can. J. Zool. 2010, 88, 668-697. [CrossRef]

41. Milet-Pinheiro, P.; Ayasse, M.; Schlindwein, C.; Dobson, H.E.; Dötterl, S. Host location by visual and olfactory floral cues in an oligolectic bee: Innate and learned behavior. Behav. Ecol. 2012, 23, 531-538. [CrossRef]

42. Rachersberger, M.; Cordeiro, G.D.; Schäffler, I.; Dötterl, S. Honeybee pollinators use visual and floral scent cues to find Apple (Malus domestica) flowers. J. Agric. Food Chem. 2019, 67, 13221-13227. [CrossRef] [PubMed]

43. Warrant, E.J.; Kelber, A.; Wallén, R.; Wcislo, W. Ocellar optics in nocturnal and diurnal bees and wasps. Arthropod Struct. Dev. 2006, 35, 293-305. [CrossRef]

44. Greiner, B.; Ribi, W.A.; Warrant, E.J. Retinal and optical adaptations for nocturnal vision in the halictid bee Megalopta genalis. Cell Tissue Res. 2004, 316, 377-390. [CrossRef]

45. Somanathan, H.; Warrant, E.J.; Borges, R.M.; Wallén, R.; Kelber, A. Resolution and sensitivity of the eyes of the Asian honeybees Apis florea, Apis cerana and Apis dorsata. J. Exp. Biol. 2009, 212, 2448-2453. [CrossRef]

46. Jander, U.; Jander, R. Allometry and resolution of bee eyes (Apoidea). Arthropod Struct. Dev. 2002, 30, 179-193. [CrossRef]

47. Greiner, B.; Ribi, W.A.; Wcislo, W.T.; Warrant, E.J. Neural organization in the first optic ganglion of the nocturnal bee Megalopta genalis. Cell Tissue Res. 2004, 318, 429-437. [CrossRef] [PubMed]

48. Somanathan, H.; Kelber, A.; Borges, R.M.; Wallén, R.; Warrant, E.J. Visual ecology of Indian carpenter bees II: Adaptations of eyes and ocelli to nocturnal and diurnal lifestyles. J. Comp. Physiol. A 2009, 195, 571-583. [CrossRef]

49. Berry, R.P.; Wcislo, W.T.; Warrant, E.J. Ocellar adaptations for dim light vision in a nocturnal bee. J. Exp. Biol. 2011, 214, 1283-1293. [CrossRef] [PubMed]

50. Frederiksen, R.; Wcislo, W.T.; Warrant, E.J. Visual reliability and information rate in the retina of a nocturnal bee. Curr. Biol. 2008, 18, 349-353. [CrossRef]

51. Warrant, E.J. Seeing better at night: Life style, eye design and the optimum strategy of spatial and temporal summation. Vis. Res. 1999, 39, 1611-1630. [CrossRef]

52. Greiner, B.; Ribi, W.A.; Warrant, E.J. A neural network to improve dim-light vision? Dendritic fields of first-order interneurons in the nocturnal bee Megalopta genalis. Cell Tissue Res. 2005, 323, 313-320. [CrossRef]

53. Liporoni, R.; Cordeiro, G.D.; Prado, P.I.; Schlindwein, C.; Warrant, E.J.; Alves-dos-Santos, I. Light intensity regulates flower visitation in Neotropical nocturnal bees. Sci. Rep. 2020, 10, 15333. [CrossRef]

54. Kelber, A.; Roth, L.S.V. Nocturnal colour vision-Not as rare as we might think. J. Exp. Biol. 2006, 209, 781-788. [CrossRef]

55. Borges, R.M.; Somanathan, H.; Kelber, A. Patterns and processes in nocturnal and crepuscular pollination services. Q. Rev. Biol. 2016, 91, 389-418. [CrossRef]

56. Siqueira, E.; Oliveira, R.; Dötterl, S.; Cordeiro, G.D.; Alves-dos-Santos, I.; Mota, T.; Schlindwein, C. Pollination of Machaerium opacum (Fabaceae) by nocturnal and diurnal bees. Arthropod Plant Interact. 2018, 12, 633-645. [CrossRef]

57. Knudsen, J.T.; Eriksson, R.; Gershenzon, J.; Ståhl, B. Diversity and distribution of floral scent. Bot. Rev. 2006, 72, 1-120. [CrossRef]

58. Alves-dos-Santos, I.; Silva, C.I.; Pinheiro, M.; Kleinert, A.M.P. Quando um visitante floral é um polinizador? Rodriguésia 2016, 67, 295-307. [CrossRef]

59. Souza, M.A.D. Biologia Reprodutiva de Onze Espécies de Myrtaceae em Floresta de Terra Firme na Amazônia Central. Master's Thesis, Instituto Nacional de Pesquisas da Amazônia/Universidade Federal do Amazonas, Manaus, Brazil, 1996.

60. Buchmann, S.L. Buzz Pollination in Angiosperms. In Handbook of Experimental Pollination Biology; Jones, C.E., Little, R.J., Eds.; Van Nostrand \& Reinhold: New York, NY, USA, 1983; pp. 73-113.

61. Oliveira, F.S.; Ribeiro, M.H.M.; Nunez, C.V.; Albuquerque, P.M.C. Flowering phenology of Mouriri guianensis (Melastomataceae) and its interaction with the crepuscular bee Megalopta amoena (Halictidae) in the restinga of Lençóis Maranhenses National Park, Brazil. Acta Amaz. 2016, 46, 281-290. [CrossRef]

62. Franco, E.L.; Gimenes, M. Pollination of Cambessedesia wurdackii in Brazilian campo rupestre vegetation, with special reference to crepuscular bees. J. Insect Sci. 2011, 11, 1-13. [CrossRef]

63. Proença, C.E.; Gibbs, P.E. Reproductive biology of eight sympatric Myrtaceae from Central Brazil. New Phyt. 1994, 126, $343-354$. [CrossRef]

64. Faria, F.S.; Stehmann, J.R. Biologia reprodutiva de Passiflora capsularis L. e P. pohlii Mast. (Decaloba, Passifloraceae). Acta Bot. Bras. 2010, 24, 262-269. [CrossRef]

65. Cane, J.H.; Sampson, B.J.; Miller, S.A. Pollination value of male bees: The specialist bee Peponapis pruinosa (Apidae) at summer squash (Cucurbita pepo). Environ. Entomol. 2011, 40, 614-620. [CrossRef]

66. Minter, L.M.; Bessin, R.T. Evaluation of native bees as pollinators of cucurbit crops under floating row covers. Environ. Entomol. 2014, 43, 1354-1363. [CrossRef] [PubMed]

67. Janzen, D. Notes on nesting and foraging behavior of Megalopta (Hymenoptera: Halictidae) in Costa Rica. J. Kans. Entomol. Soc. 1968, 41, 342-350.

68. Mori, S.A.; Boeke, J.D. Pollination. In The Lecythidaceae of a Lowland Neotropical Forest: La Fumée Mountain, French Guiana; Mori, S.A., Ed.; Memoirs of the New York Botanical Garden: New York, NY, USA, 1987; pp. 137-155. 
69. Hopkins, M.J.G.; Hopkins, H.C.F.; Sothers, C. A Nocturnal pollination of Parkia velutina by Megalopta bees in Amazonia and its possible significance in the evolution of chiropterophily. J. Trop. Ecol. 2000, 16, 733-746. [CrossRef]

70. Schlising, R.A. Sequence and timing of bee foraging in flowers of Ipomoea and Aniseia (Convolvulaceae). Ecology 1970, 51, 1961-1967. [CrossRef]

71. Bullock, S.H.; Ayala, R.; Baker, I.; Baker, H.G. Reproductive biology of the tree Ipomoea wolcottiana (Convolvulaceae). Madroño 1987, 34, 304-314.

72. Linsley, E.G.; Cazier, M.A. Some competitive relationships among matinal and late afternoon foraging activities of caupolicanine bees in southeastern Arizona. J. Kans. Entomol. Soc. 1970, 43, 251-261.

73. Shelly, R.T.E.; Villalobos, E.M.; Buchmann, S.L.; Cane, J.H. Temporal patterns of floral visitation for two bee species foraging on Solanum. J. Kans. Entomol. Soc. 1993, 66, 319-327.

74. Piechowski, D.; Dötterl, S.; Gottsberger, G. Pollination biology and floral scent chemistry of the Neotropical chiropterophilous Parkia pendula. Plant Biol. 2010, 12, 172-182. [CrossRef] [PubMed]

75. Sazima, M.; Buzato, S.; Sazima, I. Cayaponia Cabocla (Cucurbitaceae) Parece Uma Espécie Quiropterófila. In Resumos do XLVII Congresso Nacional de Botânica; Nova Friburgo: Rio de Janeiro, Brasil, 1996; pp. 407-408.

76. Somanathan, H.; Krishna, S.; Jos, E.M.; Gowda, V.; Kelber, A.; Borges, R.M. Nocturnal bees feed on diurnal leftovers and pay the price of day-night lifestyle transition. Front. Ecol. Evol. 2020, 8, 566964. [CrossRef]

77. Lorenzi, H. Brazilian Trees: A Guide to the Identification and Cultivation of Brazilian Native Trees; Instituto Plantarum de Estudos da Flora: Nova Odessa, Brazil, 2002; p. 384.

78. Nadia, T.L.; Machado, I.C.; Lopes, A.V. Polinização de Spondias tuberosa Arruda (Anacardiaceae) e análise da partilha de polinizadores com Ziziphus joazeiro Mart. (Rhamnaceae), espécies frutíferas e endêmicas da caatinga. Rev. Bras. Bot. 2007, 30, 89-100. [CrossRef]

79. Mitchell, J.D.; Daly, D.C. A revision of Spondias L. (Anacardiaceae) in the Neotropics. PhytoKeys 2015, 55, 1-92. [CrossRef]

80. Fronk, W.D.; Slater, J.A. Insect fauna of cucurbit flowers. J. Kans. Entomol. Soc. 1956, 29, 141-145.

81. Ordway, E.; Buchmann, S.L.; Kuehl, R.O.; Shipman, C.W. Pollen dispersal in Cucurbita foetidissima (Cucurbitaceae) by bees of the genera Apis, Peponapis and Xenoglossa (Hymenoptera: Apidae, Anthophoridae). J. Kans. Entomol. Soc. 1987, 60, 489-503.

82. Caetano, C.A.; Cordeiro, G.D.; Alves-dos-Santos, I. Plants visited by crepuscular-nocturnal bees. 2021. manuscript in preparation.

83. Burgett, M.; Sukumalanand, P.; Vorwohl, G. Pollen species resources for Xylocopa (Nyctomelitta) tranquebarica (F.), a night-flying carpenter bee (Hymenoptera: Apidae) of Southeast Asia. Sci. Asia 2005, 31, 65-68. [CrossRef]

84. Araujo, F.F.; Araújo, P.C.S.; Schlindwein, C. Competition between native bees and introduced honey bees on flowers of Campomanesia pubescens. 2021; manuscript in preparation.

85. Falcão, M.A.; Chavéz Flores, W.B.; Ferreira, S.A.N.; Clement, C.R.; Barros, M.J.B.; Brito, J.M.C.; Santos, T.C.T. Aspectos fenológicos e ecológicos do araçá-boi (Eugenia stipitata McVaugh) na Amazônia Central. I. Plantas juvenís. Acta Amaz. 1988, 18, 27-38. [CrossRef]

86. Ferreira, G.A.C. Camu-Camu (Myrciaria dubia (Kunth) McVaugh) e Seus Polinizadores: Produtividade, Diversidade e Interações na Amazônia Central, Brasil. Master's Thesis, Instituto Nacional de Pesquisas da Amazônia/Pós-Graduação em Botânica, Manaus, Brazil, 2020.

87. Falcão, M.A.; Fereira, S.A.N.; Clement, C.R.; Santos, T.C.; Souza, R.M. Crescimento e fenologia de Araçá-Pera (Psidium acutangulum DC). Acta Amaz. 1992, 22, 285-293. [CrossRef]

88. Silva, C.I.; Pacheco-Filho, A.J.S.; Toppa, R.H.; Arena, M.V.N.; Oliveira, P.E. Seasonal and vertical distribution of floral resources and its implications for the conservation of pollinators. Flora 2021, 278, 151787. [CrossRef]

89. Bohart, G.E. Notes on the biology and larval morphology of Xenoglossa strenua (Hymenoptera: Apoidea). Pan Pac. Entomol. 1964, 40,174 .

90. Wolda, H.; Roubik, D.W. Nocturnal bee abundance and seasonal bee activity in a Panamanian forest. Ecology 1986, 67, 426-433. [CrossRef]

91. Knop, E.; Zoller, L.; Ryser, R.; Gerpe, C.; Hörler, M.; Fontaine, C. Artificial light at night as a new threat to pollination. Nature 2017, 548, 206-209. [CrossRef]

92. Macgregor, C.J.; Scott-Brown, A.S. Nocturnal pollination: An overlooked ecosystem service vulnerable to environmental change. Emerg. Top. Life Sci. 2020, 4, 19-32. [CrossRef]

93. Straka, T.M.; von der Lippe, M.; Voigt, C.C.; Gandy, M.; Kowarik, I.; Buchholz, S. Light pollution impairs urban nocturnal pollinators but less so in areas with high tree cover. Sci. Total Environ. 2021, 778, 146244. [CrossRef] [PubMed] 